\title{
The International Kâtip Chalabi Symposium
}

The Constantinople-born Mustafa bin Abdullah Kâtip Chalabi (popularly known as Haji Khalifa [1609-57]) was one of the most notable Muslim scholars of his time. Kâtip Chalabi, as he is known as in Turkish circles, was a reformist scholar known for his intellectual contributions to the social sciences (viz., [Ottoman] history, geography, and economics) and his invaluable biobibliographical text Kashfal-Zunün, which contains over 14,000 entries. He is generally considered as one of Ottoman Turkey's most productive authors, for his writings provided an invaluable input to "the classification of knowledge" systems. For this reason, the Istanbul Foundation for Research and Education (ISAR; http://isar.academia.edu), the Turkish Centre for Islamic Studies (ISAM; http://english.isam.org), and the Cairo-based Institute of Arabic Manuscripts (MSC; www.manuscriptcenter.org) decided to co-host a March 6-8, 2015, symposium to celebrate and address his contributions.

The joint Committee for the International Kâtip Chalabi Symposium chose "Bibliography and the Classification of Knowledge in Islamic Civilization" as its main theme and set numerous goals, among them to (a) raise basic issues related to the Islamic classification of knowledge and bibliography, (b) reveal how this tradition can be reconsidered with respect to the discipline of bibliography, which has shifted into a new phase due to theoretical and practical developments in today's world; (c) provide the necessary basis for discussing his scholarly achievements; and (d) offer foundations for future research that would build upon his bibliographic encyclopedia Kashfal-Zunūn 'an Asāmī al-Kutub wa al-Funūn (The Removal of Doubt from the Names of Books and the Arts).

Since it is beyond the scope of this brief report to comment on each presentation, most of which were delivered in Arabic and Turkish with simultaneous translations, I have decided to provide a general overview of a selection of papers from each thematic session.

Ahmad Shawqi Benbin (Al-Khazanat al-Malakiyyah al-Hasaniyyah, Morocco), one of the first speakers, addressed "Kashf al-Zunūn and International Bibliography," which related directly to the symposium's general theme of "Kâtip Chelebi: Philosophy of the Sciences of Bibliography and Classification." While offering a historical context within which to view Chalabi's intellectual output, he traced the science of bibliography back to Abu al-Faraj 
Muhammad ibn Ishaq al-Nadim (d. 995 or 998), compiler of Kitāb al-Fihrist, and then tied it to the work of Swiss bibliographer Conrad Gessner (d. 1565), compiler of the first known Bibliotheca Universalis, which contained 12,000 Latin, Greek, and Hebrew titles. He thereafter showed, among other things, how Chalabi's work contributed to the scientific classification of knowledge.

Toward the close of the day, the second theme reflected upon "Islamic Bibliography: History, Vision, and Comparison." Ayman Fuad Sayyid (alAzhar University), one of this session's four panelists, investigated "The Characteristics of the Muslim Viewpoint regarding Bibliographical Compilation." In contrast to Benbin, he provided a broader overview of bibliographical studies by referring to key scholars in the Muslim world across the centuries, including al-Nadim's famous work.

On the second day, the third thematic focus was "Islamic Bibliography and the Classification of Sciences: Contemporary Efforts." Muhammed Haron's (University of Botswana) "Towards an Annotated Bibliography of Sub-Saharan Africa's Muslims," one of the three papers presented, looked at different bibliographical compilations that concentrated on "Muslims in Africa (excluding North Africa)." In particular he revisited the work of Paul Schrijver, who is based at Leiden University's African Study Centre. Apart from critically assessing Schrijver's work, Haron suggested compiling an annotated bibliography as a better alternative. He was joined by Seyfullah Korkmaz (Erciyes University), who spoke about "Ali Riza Karabulut as an Important Contemporary Author in the Classification of Sciences and Bibliography."

The fourth theme, "Islamic Classification of Sciences: Epistemological Beginnings," comprised five panelists. Two of them were Tuncay Basoglu (ISAM) and Eyup Sahin (Ankara University); the former addressed "The Classification of Sciences in al-Farabi and Ibn Hazm," whereas the latter zoomed in on "The Transmission of al-Farabi's Classification of Sciences to the Latin World and Its Reception." These two papers overlapped to some extent, given their common discourse about al-Farabi's (d. 950) contribution to the Islamic sciences. The fifth sub-theme dealt with "The Bibliographical Study and Comparative (Perspectives) in Kashf al-Zunūn." In this session Abdullah al-Rushdi (Dar al-Hadith al-Hasaniyyah, Morocco) reviewed "Kashf al-Zunūn and (Its) Method: The Characteristics of Bibliographical Composition," and Virginia Hernandez (Spanish National Research Council) considered the works of "Local Scholars in a Global Work: Andalusi and Maghrebi Tabaqāt Works in Kashfal-Zunün." Al-Rushdi's paper evaluated the key characteristics of Kashf al-Zunūn, and Hernandez's presentation assessed the dynamics of knowledge transfer (e.g. the Andalusian Țabaqāt [namely, Țabaqāt al-Umam of Qāḍ̂̀ Sa id 
al-Andalusi (d.1070)] into Chalabi's bibliography) in the Muslim heartlands during the pre-modern era.

The day's final session closed with the sixth session, which gave some insight into the "Works on General Classification in Kashf al-Zunün." On this four-member panel, Muhammad Aydan (Qatar University) reflected on "The Genius of Kâtip Chalabi in Classification: The Introduction of Kashf alZunūn" and Walid Ahmad Saleh (University of Toronto) discoursed about "The Hāshìyah (Gloss) and the Matn (Text): Kâtip Chalabi and the Classification of Science in the Post-Classical Period." Aydan explored Chalabi's perceptions regarding the definition and understanding of Islamic sciences, and Saleh argued that his text was the first one to admit "gloss" into a bibliographical compilation; he used al-Zamakhshari's Al-Kashshäf and al-Baydawi's Anwār al-Tanzīl to illustrate his points.

Five panelists were grouped under the seventh theme: Sciences in Kashf al-Zunūn. Nasir al-Din Abu Hudayr (University of Birzayt) examined "Kâtip Chalabi's Method of Classifying Language Sciences and Scholars in Kashf al-Zunūn," Muhammad Mansur al-Hawi (University of King Khalid) discussed the "Works Produced by Yemeni Scholars in Kashf al-Zunūn." Both scholars engaged critically with Kashf al-Zunün's contents by underscoring some of its shortcomings or incorrect entries, which they strongly recommended should be rectified in a revised edition.

The penultimate thematic panel, "The Issues regarding the Development of Islamic Bibliography: The Case of Fiqh," had five presenters. Omer Turker (Marmara University) offered an insight into "The Place of Religious Sciences in Kâtip Chalabi's Classification: A Comparative Study," and Abdul Hakim al-Anis (Dar al-Shu'un, Dubai) surveyed "The History of the (Arabic) Book in the Light of Kashf al-Zunūn." The final thematic panel covered "Issues on Developing the Methodological Structure of Kashfal-Zunün." The first of the four presenters was Abid al-Mashukhi (University of King Saud), who studied the actual "Sources of Kashf al-Zunün," and Hasan Uthman (University of Umm al-Qura), the final presenter, deliberated on "Kashf al-Zunün and the Text: Printed Books, Translations, and Studies."

The academic gathering "A Broad Vision for the Future" closed the event with a session that (a) evaluated its outcomes (Tuncay Basoglu [ISAM]), (b) proposed the setting up of a special Kâtip Chalabi website (Recep Senturk [Fatih Sultan Mehmet Vakif University/ISAR]), (c) reflected on the symposium's scholarly horizon (Muhammad Abdul-Wahhab Jalal [French University, Egypt]), and (d) commented "on the revival of the Kâtip Chalabi Legacy" (Mahmud Misri [Sultan Muhamammad al-Fatih Waqaf University]). 
On the whole this was an illuminating symposium, for it (1) caused scholars to critically engage with Kâtip Chalabi's ideas and specifically his monumental Kashf al-Zunün and (2) demonstrated the extent of his invaluable contribution to the "classification of knowledge" system in general. Through the ongoing discussions and debates, one was able to acquire a greater appreciation for his bibliographical scholarship. Besides the social scientists, those specialists in library and information science would have benefitted a great deal from the scholarly deliberations, since most of the issues raised are relevant to their own specializations. The organizers have decided to publish the set of papers, after a peer review process, initially in the Turkish Journal of Islamic Studies and thereafter in book form.

Muhammed Haron Associate Professor of Relgious Studies, Department of Theology \& Religious Studies University of Botswana, Gaborone, Botswana Associate Researcher, Department of Religion Studies University of Johannesburg, Johannesburg, South Africa 